は短縮，肥厚した弁下構造の温存は左室収縮能への関与 は少ないものと考えられた。

$$
\text { 結語 }
$$

僧帽弁置換術後遠隔期の検討を行った.

1. MR 例に扔いて左室容量は, 腱索温存群, 非温存 群ともに術後縮小し，群間に差は認められなかった。

2. MR 例における左室壁局所收縮能は，温存群では 術後あ良好であるが，非温存群では左室長軸方向の収縮 が低下していた.
3. MS 例においては両群間に明らかな差を認めなか った.

文 献 1) Lillehei, C. W. et al.: J. Thorac. Cardiovasc. Surg. $47: 532,1964$. 2) Hetzer, R. et al. : Thorac. Cardiovasc. Surg. 31:291, 1983. 3) 浅野献一ほ加: 日外会誌 $86: 233$, 1985. 4) Asano, K. : Heart valve replacement and reconstruction. ed. Starek, P.J.K., p. 279, Year Book Medical Pub., Chicago, 1987. 5) 中島 淳ほ加: 日胸外会誌 $37: 463,1989$. 6) Hensen, D. E. et al. : J. Thorac. Cardiovasc. Surg. $93: 45,1987.7)$ David, T.E. et al. : J. Thorac. Cardiovasc. Surg. 88: 718, 1984. 8) Yagyu, K. et al.: Thorac. Cardiovasc. Surg. 35 : 166, 1987.

\title{
10 僧帽弁閉鎖不全における弁構造温存・人工弁植込み手術
}

\begin{tabular}{|c|c|c|c|c|c|c|c|c|c|c|c|c|c|c|}
\hline & \multicolumn{14}{|c|}{ 大分医科大学 第 2 外科 } \\
\hline & 玉 & 哲 & 生 & 高 & 崎 & 英 & 巳 & 森 & & 義 & 顕 & 岡 & 敬 & $=$ \\
\hline & 光 & & 修 & 藤 & 島 & 公 & 典 & 田 & 中 & 康 & 一 & 一万田 & 充 & 俊 \\
\hline & & & & 内 & 田 & 雄 & $\equiv$ & 調 & & 亟 & 治 & & & \\
\hline
\end{tabular}

弁膜症における弁置換手術は僧帽弁疾患，大動脈疾患 之屯，人工弁構造・材質の改良之心筋保護法の発達によ り成績は向上した，手術成績および術後の心機能に関し て，大動脈弁置換術と僧帽弁置換術のあいだでは大動脈 弁置換術が手術成績は優れているとの報告がある。 た，僧帽弁閉銷不全において，弁置換術之弁形成術のあ いだでは弁形成術のほうが優れていると報告されてい る. この原因として僧帽弁置換術に扰いては腱索, 乳頭 筋などの并構造を切除するため心収縮力が低下するとと か原因之説明されている。

著者らは弁構造を温存して人工弁植込久術を行った群 が従来の人工弁置換術を行った群より優れているかどう か術直後と遠隔期における心機能を比較して報告した.

\section{対象}

1987 年 11 月より 1989 年 12 月までに大分医科大学第 2 外科学教室に扮いて, 僧帽弁閉鎖不全に対して弁構造 を温存して人工弁植込み術を行った 8 症例を $\mathrm{A}$ 群とし た. 同期間内に同疾患に対し弁構造を切除し人工并置換 術を行い心機能検査が行われた 7 症例を B 群とした. A 群は男性 4 例，女性 4 例で平均年齢は $42 \pm 8$ 歳で，B群 は男性 4 例, 女性 3 例で平均年齢は $50 \pm 6$ 歳であった。

\section{方法}

使用した人工弁は，A群の 8 例のうち 7 例が Medtronic-Hall 弁 1 例が St. Jude Medical 弁でB群の 7 例で はすべて Medtronic-Hall 弁であった。

\section{手術手技}

左心房を十分に観察し僧帽弁構造を弁下組織を含めて 肥厚, 短縮, 腱索の癒合, 石灰化などリウマチ性, 感染 性心内膜炎の所見が存在しないととを確認する．弁尖の 逸脱，腱索の延長，腱索断裂などによる閉鎖不全が本術 式の適応である. 著者らの 8 症例は弁組織の変性による ひ薄化，腱索の延長・断裂を認めた．腱索の断裂の場合 は腱索のみを切断した。背面にはタオル・スポンジな ど腱索，乳頭筋の変形をきたすすのは用いないで心筋が 完全に弛緩した状態で弁尖をピンセットで注持し腱索を たるみのない状態に緊張させる. この状態で spaghetti 付き 2-0 ticron 糸を用い一度弁輪をすくった後さらに 弁尖を通し水平 mattress 法にて腱索・弁尖を弁輸へ引 き寄せる，全周に同様の運針を行い人工弁の縫着輸に縫 合固定する．Disk が腱索に接触しないととを確認する. 心腔内の空気抜きを行い左心房を閉じる. 


\section{検 討 項目}

手術当日㧍よび遠隔期 (心カテーテル所見は術後 1 か 月, その他は 3 か月加ら 3 年) の心機能を A 群と B 群 で比較した. 急性期の心機能の指標として心拍出係数 (CI : $l / \mathrm{min} / \mathrm{m}^{2}$ ), 左心室仕事係数 (LVWI $: \mathrm{kg} \cdot \mathrm{m} / \mathrm{min}$ ) $\mathrm{m}^{2}$ ) を術直後，3，6，12，18 時間後の推移で比較した. 遠隔期の改善度を NYHA, CTR, CI, EF, 心エコー困に よる LAD, LVEDVI, \%FS および radial method によ る5区域 (1:anterobasal, 2: anterolateral, 3: apical,
4: diaphragmatic, 5: posterobasal) の壁運動につき A. B 群で比較した. 壁運動の測定には術後 $1 \sim 2$ か月 の左室造影の RAO 像を用いた.

$$
\text { 結果 }
$$

CI はA群で 3. $7 \pm 1.0,4.1 \pm 0.4,3.7 \pm 1.0,3.8 \pm 1.6$, 3. $8 \pm 1.2$, B群で $3.5 \pm 0.8,3.1 \pm 0.4,3.0 \pm 0.5,2.9 \pm$ $0.4,2.9 \pm 0.3$ であり, 直後以外はすべてA群が良好で あった $(p<0.05)$. LVWI はA 群で $5.5 \pm 1.9,5.2 \pm 1.5$,

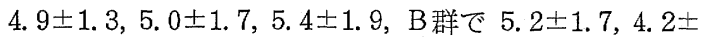

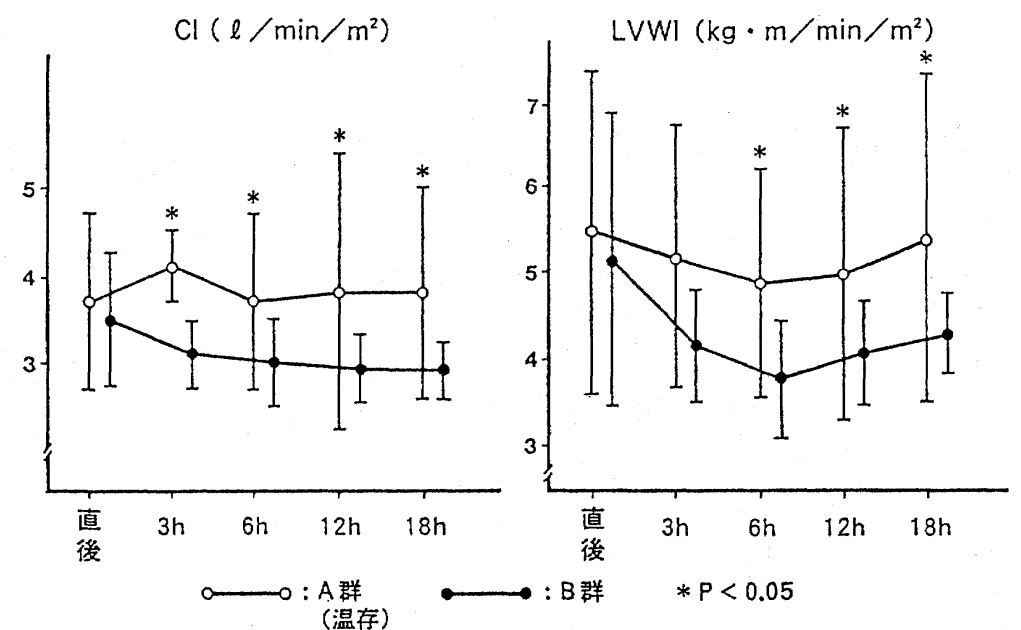

図 1 手術当日の血行動態の推移

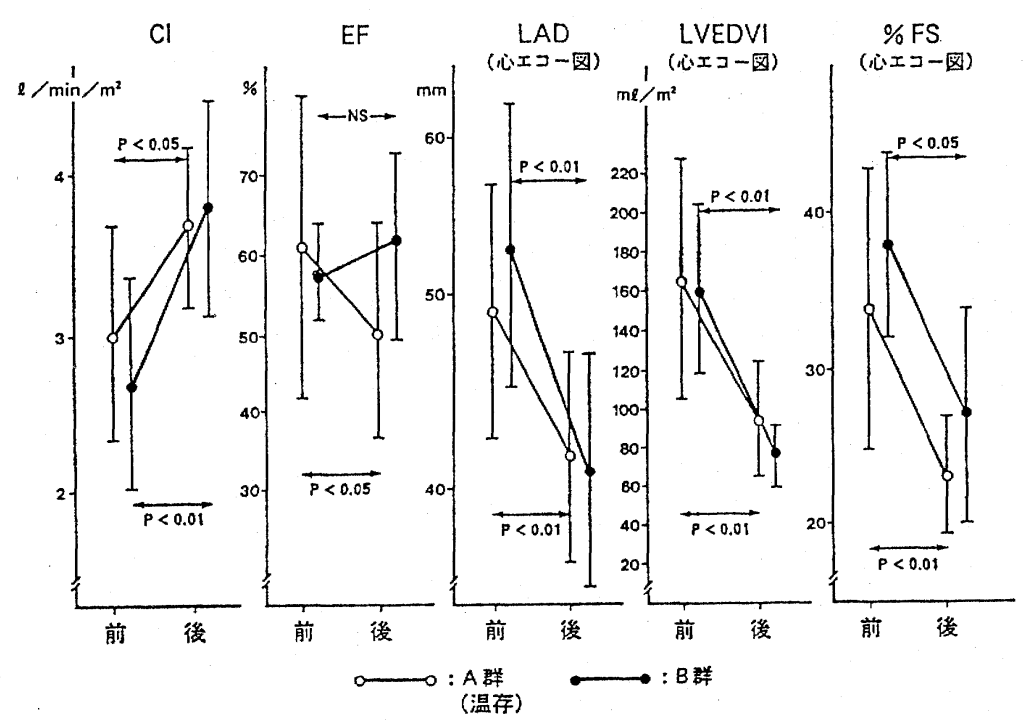

図 2 遠隔期心機能推移 
$0.6,3.8 \pm 0.7,4.1 \pm 0.6,4.3 \pm 0.5$, であり, $6,12,18$ 時間後で $\mathrm{A}$ 群が有意に優れていた $(p<0.05)$ (図 1 ).

術後の NYHA はA群の 1 例が 2 度に止まった以外 は前例 1 度に改善した. CTR はA群で $62 \pm 9 \%$ から $55 \pm 4 \%$ 几，B群で $58 \pm 5 \%$ から $53 \pm 3 \%$ ，画群之 も有意に改善した $(p<0.05) . \mathrm{CI}, \mathrm{EF}, \mathrm{LAD}, \mathrm{LVEDVI}$, \%FS は図 2 に示した. CI, LAD, LVEDVIはA・B群 とも有意に改善したが，EF は対象が MR であるため術 前值が高く両群とも術前，術後を比較することは適当で はないと考えられた％\%F は両群と屯術後有意に低下 した，すなわち，これらの指標からは術後遠隔期には差 がないととがわかった. 壁運動は seg 1 から seg 5 へ, A 群では術後すべて低下傾向を示したがB群ではすべて 増加傾向を示した. しかし, 術後, 両群の間の差は認め られなかった。

\section{考察}

僧帽弁膜症の外科治療の目的は，十分な弁口面積を保 ち，弁逆流を防止し，さらに左心室収縮力を維持あるい は回復させることにある．僧帽弁狭窄症と閉鎖不全では 左心室に対する容量負荷の点でまったく異なる．僧帽弁 閉鎖不全に対する術式は弁形成術と弁置換術に大別され るが現在使用されている人工弁においては弁口面積と逆 流に関しては問題なく熟練した術者により行われた弁形 成術と大差ないと考えられる.

しかし，左心室収縮力の維持，回復に関して従来の弁 置換術では，腱索・乳頭筋を切断するため弁形成術に比 し劣るとの報告が多い，弁形成術はすべての僧帽弁閉鎖 不全に応用しうるあのではないとと，完全に逆流を防止 するには芸術的とあいえる外科医の熟練を要求されるこ とから両術式を併用した弁構造を温存して人工弁を縫着
する術式が報告されている.

Rushmer ${ }^{1)}$ の理論的根拠に基づき Lellihei ${ }^{2)}$ が弁構造 を温存した人工弁置換術を推奖した. そのとろの人工弁 は ball 弁であったためと, Rastelli ${ }^{32}$ らの否定的な実験 結果のため十数年間省みられなかった. 1980 年代になり David $^{4)}$, Hetzer ${ }^{5)}$ らが二葉機械弁を用い弁構造を温存 して人工弁縫着術を行い，左心室後壁破裂の防止，左心 室収縮性の点で優れていることを報告して以来多数の追 試が行われている. 本邦においても, 浅野6), 三木 ${ }^{7)}$, 鬼 塚 ${ }^{8)}$ らは弁温存術式が左心室局所収縮性からみて優れて いることを報告している．報告者それぞれ術式が異なっ ており，われわれは前尖・後尖，それに付着した腱索， 乳頭筋を切除せず一葉機械弁である Medtronic-Hall 弁 を縫着した。

手術当日の心機能は従来の弁置換術式に比し優れてい たが遠隔期には左室壁運動加ら見ても両術式に差は見ら れなかった．われわれの結果が諸報告と異なった原因と して，前尖の腱索を移動することなく弁輪へ縫縮する際 の緊張度の不適切, 使用した人工弁の構造上の問題が考 えられるが後者に関しては Medtronic-Hall 弁は従来の 僧帽弁置換術に多数使用し良好な結果を得ていることか ら考えにくい，前尖側の腱索の温存法に改善の余地があ るあのと考える.

文 献 1) Rushmer, F.F.: Am. J. Physiol. 184: 188, 1956. 2) Lellihei, C.W. et al.: J. Thorac. Cardiovasc. Surg. 47: 532, 1964. 3) Rastelli, G.C. et al.: Circulation 35, 36 (Suppl. 1) : 1, 1967. 4) David, T.E. et al. : Can. J. Surg. $24: 236,1981$. 5) Hetzer, R. et al.: Thorac. Cardiovasc. Surg. 31: 291，1983. 6) 浅野献一ほ加：日外会誌 86:233，1985. 7) 三木成仁ほか：胸部外科 40：1047，1987. 8) 鬼塚敏男ほか: 胸部外科 $41: 865,1988$. 